\title{
REMOVAL OF COD FROM OIL RECOVERY INDUSTRY WASTEWATER BY THE ADVANCED OXIDATION PROCESSES (AOP) BASED ON $\mathrm{H}_{2} \mathrm{O}_{2}$
}

\author{
A.R. DINCER \\ N. KARAKAYA \\ E. GUNES \\ Y. GUNES
}

Received: 21/06/07

Accepted: 10/09/07
Department of Environmental Engineering

Namik Kemal University, Corlu

Tekirdag, Turkey

\begin{abstract}
The combinations of $\mathrm{H}_{2} \mathrm{O}_{2} / \mathrm{Fe}^{+2}, \mathrm{UV} / \mathrm{H}_{2} \mathrm{O}_{2} / \mathrm{Fe}^{+2}$ and $\mathrm{UV} / \mathrm{H}_{2} \mathrm{O}_{2}$ process were investigated on treatment of oil recovery industry wastewater. Treatment of oil recovery industry wastewater, a typical high pollution strength industrial wastewater (chemical oxygen deman (COD): 21000 $\mathrm{mg} \mathrm{l}^{-1}$, biological oxygen demand (BOD): $8000 \mathrm{mg} \mathrm{l}^{-1}$, oil and grease:1140 $\mathrm{mg} \mathrm{l}^{-1}$, total dissolved solids (TDS): $37000 \mathrm{mg} \mathrm{l}^{-1}$, total suspended solids: $2580 \mathrm{mg} \mathrm{l}^{-1}$ ), was carried out by batch oxidation processes.

The optimal mass ratio for $\mathrm{H}_{2} \mathrm{O}_{2} / \mathrm{Fe}^{+2}$ yielding the highest $\mathrm{COD}$ removal was found to be 8.658 corresponding to $200.52 \mathrm{~g}^{-1} \mathrm{H}_{2} \mathrm{O}_{2}$ and $23.16 \mathrm{~g} \mathrm{I}^{-1} \mathrm{Fe}^{+2}$ concentrations for 60 minutes reaction time. Fenton process gave a maximum COD reduction of $86 \%$ (from 21000 to 2980 $\mathrm{mg} \mathrm{l}^{-1}$ ) and the combination of $\mathrm{UV} / \mathrm{H}_{2} \mathrm{O}_{2}$ gave a COD reduction of $39 \%$ (from 21000 to 12730).

The percentage of removal, after the total reaction time (3.5h), $\mathrm{H}_{2} \mathrm{O}_{2}: 8.4 \mathrm{~g} \mathrm{I}^{-1}$ and Fe $\mathrm{Fe}^{+2}: 0.05 \mathrm{~g}$ $\mathrm{I}^{-1}$, in the photo Fenton process, corresponded to $81 \%$ of the total initial COD $\left(4200 \mathrm{mg} \mathrm{l}^{-1}\right)$. The oxidative ability of the UV/Fe ${ }^{+2} / \mathrm{H}_{2} \mathrm{O}_{2}$ process $(81 \%)$ was greater than that of the $\mathrm{UV} / \mathrm{H}_{2} \mathrm{O}_{2}$ process $(55 \%)$ for $80 \%$ diluted wastewater. COD removal efficiency for $\mathrm{UV} / \mathrm{H}_{2} \mathrm{O}_{2}$ process $\left(\mathrm{COD} / \mathrm{H}_{2} \mathrm{O}_{2}=1 / 2(\mathrm{w} / \mathrm{w})\right)$ was $90 \%, 55 \%$, and 39 when initial COD was 1050,4200 , and 21000 $\mathrm{mg} \mathrm{l}^{-1}$, respectively, whereas COD removal was 943,2320 , and $8270 \mathrm{mg} \mathrm{l}^{-1}$, respectively.
\end{abstract}

KEYWORDs: Oil recovery industry; Fenton; Photo-Fenton; UV plus hydrogen peroxide

\section{INTRODUCTION}

Advanced oxidation processes (AOP) are defined as oxidation processes in which hydroxyl radicals are the main oxidants involved. Advanced oxidation processes (AOPs) are emerging and promising technology both as an alternative treatment to conventional wastewater treatment methods and enhancement of current biological treatment methods especially dealing with highly toxic and low biodegradable wastes (Chamarro et al., 2001). Fenton and Photo-Fenton oxidation processes have been employed successfully to treat different industrial wastewaters, including black olive (Benitez et al., 2001) and mineral oil contaminated wastewaters (Andreozzi et al., 2000).

The mechanism of the Fenton reaction has been known for a long time. This oxidation method is based on the use of a mixture of hydrogen peroxide and iron salts $\left(\mathrm{Fe}^{+2}\right)$ which produces hydroxyl radicals ( $\left(\mathrm{OH}\right.$ ) at acidic $\mathrm{pH}$ in ambient conditions. Both $\mathrm{H}_{2} \mathrm{O}_{2}$ and $\mathrm{Fe}^{+2}$ can react with ${ }^{\circ} \mathrm{OH}$ and therefore both can inhibit the oxidation reactions if either of them is not in the optimal dosage (Tang and Huang, 1996). Many authors suggested $\mathrm{Fe}^{+2}$ to $\mathrm{H}_{2} \mathrm{O}_{2}$ mass ratio to be optimal at 1 to 10 , but it must be optimised for particular wastewater to minimize scavenging effects (Torrades et al., 2003). The generally accepted mechanism of the Fenton process proposes that hydroxyl radicals are produced by reaction of $\mathrm{H}_{2} \mathrm{O}_{2}$ with $\mathrm{Fe}^{+2}$ which is regenerated from the reaction of $\mathrm{Fe}^{+3}$ with $\mathrm{H}_{2} \mathrm{O}_{2}$ or intermediate organic radicals (Legrini et al., 1993). This hydroxyl radical attacks organic molecules by abstracting a hydrogen atom or 
by adding to the double bonds. Organic molecules are then totally mineralized to carbon dioxide and water (Huston and Pignatello, 1999).

The photo-Fenton process $\left(\mathrm{H}_{2} \mathrm{O}_{2} / \mathrm{Fe}^{+2} / \mathrm{UV}\right)$ is one of advanced oxidation processes. This process involves the hydroxyl radical $\left({ }^{\circ} \mathrm{OH}\right)$ formation in the reaction mixture through photolysis of hydrogen peroxide $\left(\mathrm{H}_{2} \mathrm{O}_{2} / \mathrm{UV}\right)$ and Fenton reaction $\left(\mathrm{H}_{2} \mathrm{O}_{2} / \mathrm{Fe}^{+2}\right)$ (Fenton, 1894). The $\mathrm{H}_{2} \mathrm{O}_{2} / \mathrm{UV}$ or Fenton process alone was successful in removing COD from oil containing wastewaters. The peroxide dose is important in order to obtain a better degradation efficiency, while the iron concentration is important for the reaction kinetics (Chamarro et al., 2001). The $\mathrm{UV} / \mathrm{H}_{2} \mathrm{O}_{2}$ process uses ultraviolet radiation to cleave the $\mathrm{O}-\mathrm{O}$ bond in hydrogen peroxide and generate the hydroxyl radical. When UV light is absorbed directly by hydrogen peroxide, $\mathrm{OH}$ radicals are generated by photolysis of the peroxidic bond (Bolton, 1999).

The major objective of this study was to investigate the performance of single Fenton's reagent, combination of Fenton's reagent with UV (photo-Fenton process) and combination of UV radiation with hydrogen peroxide for COD removal from oil recovery industry wastewater. The following topics were also studied: wastewater characterization, effect of $\mathrm{H}_{2} \mathrm{O}_{2} / \mathrm{Fe}^{+2}$ ratios, wastewater concentration (pollution strength) and oxidation time. The wastewater samples obtained from factory were characterized according to the procedures described in Standard Methods (APHA, 1992). It was found that the Fenton, photo Fenton and combination of UV and $\mathrm{H}_{2} \mathrm{O}_{2}$ processes have the potential to reduce the COD of oil recovery industry wastewater.

\section{MATERIAL AND METHOD}

\subsection{Wastewater Characterization}

The physicochemical characteristic of the wastewater are summarized in Table 1. The wastewater used in this work is the effluent of an actual oil recovery industry (Çorlu-Tekirdağ, Turkey).

Table1. Characteristic of wastewater (equalization tank) used in Fenton, photo-Fenton and $\mathrm{UV} / \mathrm{H}_{2} \mathrm{O}_{2}$ processes.

\begin{tabular}{llc}
\hline Parameter & Units & Value \\
\hline $\mathrm{pH}$ & & 2.5 \\
Chemical Oxygen Demand (COD) & $\mathrm{mg} \mathrm{l}^{-1}$ & 21000 \\
Biochemical Oxygen Demand (BOD $)$ & $\mathrm{mg} \mathrm{l}^{-1}$ & 8000 \\
Oil and Grease & $\mathrm{mg} \mathrm{l}^{-1}$ & 1140 \\
$\mathrm{SO}_{4}^{-2}$ & $\mathrm{mg} \mathrm{l}^{-1}$ & 12400 \\
$\mathrm{Cl}^{-1}$ & $\mathrm{mg} \mathrm{l}^{-1}$ & 375 \\
$\mathrm{NO}_{3}-\mathrm{N}$ & $\mathrm{mg} \mathrm{l}^{-1}$ & 9.0 \\
$\mathrm{NH}_{4}-\mathrm{N}$ & $\mathrm{mg} \mathrm{l}^{-1}$ & 69 \\
Total Suspended Solids (TSS) & $\mathrm{mg} \mathrm{l}^{-1}$ & 2580 \\
Total Dissolved Solids (TDS) & $\mathrm{mg} \mathrm{l}^{-1}$ & 37000 \\
Biodegradability (BOD & & 0.38 \\
\hline
\end{tabular}

\subsection{Reagents}

Hydrogen peroxide were prepared using the technical grade $\left(50.59 \%\right.$; density: $1.13 \mathrm{~kg} \mathrm{l}^{-1}$ ) $\mathrm{H}_{2} \mathrm{O}_{2}$. Ferrous sulphate heptahydrate $\left(\mathrm{FeSO}_{4} \cdot 7 \mathrm{H}_{2} \mathrm{O}\right.$, Merck) was used as source of $\mathrm{Fe}^{+2}$ in the Fenton and photo Fenton treatment. All solutions of $\mathrm{H}_{2} \mathrm{O}_{2}, \mathrm{Fe}^{+2}, \mathrm{NaOH}$ and $\mathrm{H}_{2} \mathrm{SO}_{4}$ were prepared with deionized water and were made on each experimental day.

\subsection{Experimental procedure}

A sketch of the laboratory reactor (Fenton process) is shown in Fig.1(b). The experiments were performed in a round-bottomed flask. In the single Fenton's reagent experiments, the UV reactor was not connected to Fenton reactor. The reaction solution was stirred with a magnetic stirrer using a constant speed at $200 \mathrm{rpm}$ to maintain a well-mixed solution during the experiments. In every assay, a $300 \mathrm{ml}$ sample was placed into $500 \mathrm{ml}$ flask, which was submerged in a water bath for temperature control. The optimum $\mathrm{pH}$ for Fenton, photo-Fenton and $\mathrm{UV} / \mathrm{H}_{2} \mathrm{O}_{2}$ for treatment of oil industry wastewater was accepted to be $3 \pm 0.1$ based on 
previous studies (McGinnis et al., 2000; Garcia Montano et al., 2006). In every case, the reaction was started by adding the dose of hydrogen peroxide. All experiments were carried out in batch mode.

The initial concentration of wastewater had $21000 \mathrm{mg} \mathrm{l}^{-1} \mathrm{COD}$ and solution volume was 300 $\mathrm{ml}$. For Fenton experiments, wastewater was used without dilution. Several set of experiments were carried out to determine the range of hydrogen peroxide and iron needed to obtain optimum results. In the first set of experiments, the amount of $\mathrm{H}_{2} \mathrm{O}_{2}$ added was changed between 22.28 and $111.4 \mathrm{~g} \mathrm{l}^{-1}$ when Fe${ }^{+2}$ concentration was kept constant at $7.72 \mathrm{~g} \mathrm{l}^{-1}$. In the second set of experiments, oxidation experiments were performed varying the concentration of $\mathrm{H}_{2} \mathrm{O}_{2}\left(22.28-200.52 \mathrm{~g} \mathrm{I}^{-1}\right)$ and $\mathrm{Fe}^{+2}\left(2.56-23.16 \mathrm{~g} \mathrm{I}^{-1}\right)$ and monitoring COD in samples collected at time of $60 \mathrm{~min}$.

The schematic diagram of the experimental set-up used is shown in Fig.1 (a-b) for photo Fenton and $\mathrm{UV} / \mathrm{H}_{2} \mathrm{O}_{2}$ processes. A low pressure mercury vapor lamp (model Hg F15-05, Eurotech) with a nominal power of $12 \mathrm{~W}$ (according to the manufacturer) was used in the UV irradiation processes at $254 \mathrm{~nm}$. The UV lamp enclosed in a quartz sleeve with an inner diameter of $22 \mathrm{~mm}$ and a length of $225 \mathrm{~mm}$ was positioned within the centre of a $250 \mathrm{ml}$ cylindrical stainless steel reactor as the light source.

The UV reactor was connected to the circulation tank (Fenton reactor). The circulation tank with a total volume of $500 \mathrm{ml}$ is made in pyrex-glass and is equipped with an external water bath connected to tap water, for temperature control. The circulation tank is equipped with a magnetic bar, thermometer and $\mathrm{pH}$ meter. Circulation of the wastewater between the two tanks is made by a peristaltic pump at a rate of $2.0 \mathrm{I} \mathrm{min}^{-1}$. The total liquid volume in the system was kept at 0.3 I (Fenton reactor) +0.25 I (UV reactor). Samples were withdrawn from the circulation tank at t: $0,30,60,90,120,150,180$ and 210 minutes for the COD analysis. To determine the effect of $\mathrm{Fe}^{+2}$ concentration on the COD removal efficiency, a series of experiments (photo-Fenton) varying the concentration of iron and keeping fixed the other parameters, were carried out. Hydrogen peroxide was employed at the concentration of $8.4 \mathrm{~g} \mathrm{l}^{-1}$, while different concentration of $\mathrm{Fe}^{+2}$ were tested $\left(0.025,0.050,0.100\right.$ and $\left.0.200 \mathrm{~g} \mathrm{I}^{-1}\right)$.

In UV/ $\mathrm{H}_{2} \mathrm{O}_{2}$ oxidation process, experiments were carried out at different initial COD and $\mathrm{H}_{2} \mathrm{O}_{2}$ concentrations. In the first series, three pollution strengths of wastewater such as 5, 20 and $100 \%$ were prepared for $\mathrm{COD}$ removal at the fixed $\mathrm{COD} / \mathrm{H}_{2} \mathrm{O}_{2}$ ratio of $1 / 2$. In the second series, hydrogen peroxide was added in $\mathrm{COD} / \mathrm{H}_{2} \mathrm{O}_{2}$ weight ratios of 1:1, 1:2 and 1:4. The initial COD concentration was kept constant at $1050 \mathrm{mg} \mathrm{l}^{-1}$. Immediately after the addition of the chemicals to the reactor, the UV lamp and the peristaltic pump were turned on to initiate the reaction. All the experiments were done in duplicate for the same set of conditions. The variations were systematically within $\pm 5 \%$ of the stated values.

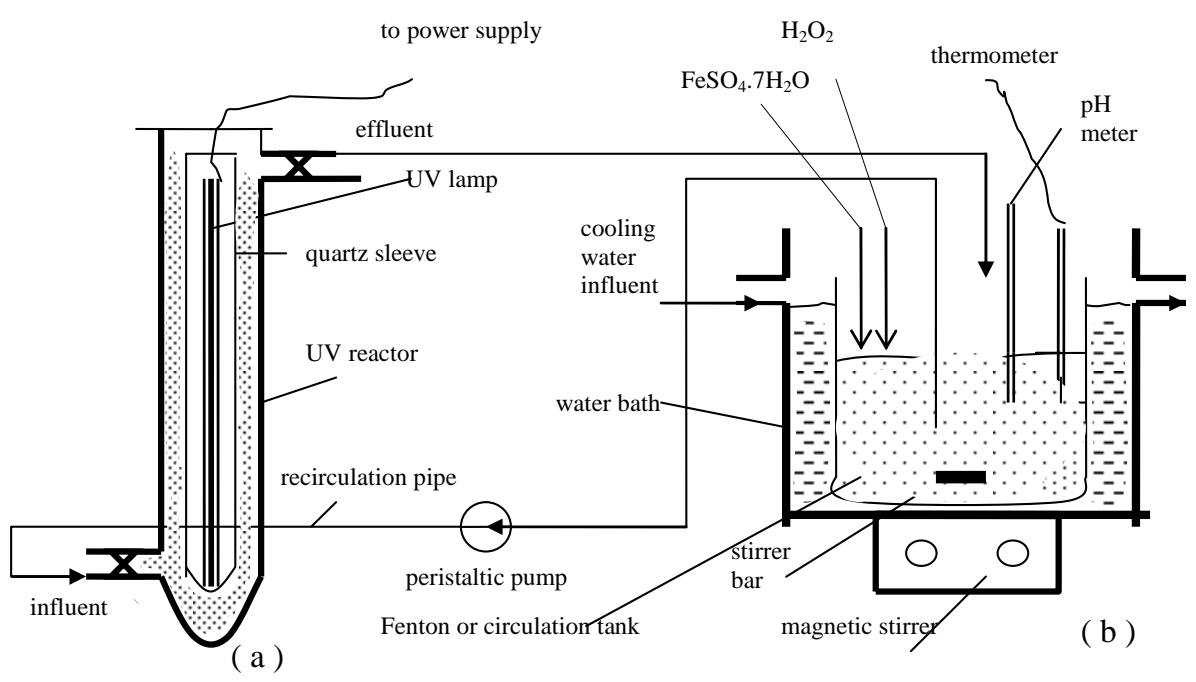

Figure 1. Schematic diagram of experimental set-up [(a) and (b)] 


\subsection{Analyses}

Chemical oxygen demand (the using dichromate reflux method), biological oxygen demand, oil and grease, phenol, total suspended solids, total dissolved solids, $\mathrm{SO}_{4}{ }^{-2}, \mathrm{Cl}^{-}, \mathrm{NO}_{3}-\mathrm{N}, \mathrm{NH}_{4}{ }^{-}$ $\mathrm{N}$ and $\mathrm{NO}_{2}^{-}$were measured in raw wastewaters by procedures described in Standard Methods (APHA, 1992). The $\mathrm{pH}$ measurements were performed using a $\mathrm{pH}$ meter (WTW340).

At selected time interval, $5 \mathrm{ml}$ of reaction mixture was taken and then analyzed for COD. The samples containing $\mathrm{H}_{2} \mathrm{O}_{2}$, which interferes with the $\mathrm{COD}$ measurements, were eliminated by the addition of $\mathrm{MnO}_{2}$ powder. Before each analysis, samples were centrifuged to remove $\mathrm{MnO}_{2}$.

\section{RESULT AND DISCUSSION}

Wastewater used in this study was obtained from oil recovery industry located in Çorlu, Tekirdağ-Turkey. Composition of the wastewater used in this study is presented in Table 1. These results indicate that this wastewater contains high load of organic and inorganic matter. Therefore, this wastewater can cause serious damage to the environment when discharged directly without proper treatment.

The $\mathrm{BOD}_{5} / \mathrm{COD}$ ratio of oil recovery industry wastewater was found to be 0.38 (Table 1 ). $\mathrm{BOD} / \mathrm{COD}$ constitutes a good measure of the biodegradability of a wastewater. This wastewater is partially biodegradable according to Chamarro et al. (2001) and Garcia Montano et al. (2006). Contaminants with a ratio of $\mathrm{BOD}_{5} / \mathrm{COD} \geq 0.4$ are generally accepted as biodegradable, while those with ratios situated among 0.2 and 0.3 units result partially biodegradable (Chamarro et al., 2001; Garcia Montano et al., 2006). Therefore, there was a need for advanced treatment processes to decrease pollutions from oil recovery industry wastewater.

Effluent $C O D$ concentration and COD removal efficiency in Fenton oxidation experiments under different conditions are presented in Fig.2 and Fig.3. The effect of $\mathrm{H}_{2} \mathrm{O}_{2}$ concentration on COD removal was examined by changing the $\mathrm{H}_{2} \mathrm{O}_{2}$ concentration between 22.28 and $111.4 \mathrm{~g} \mathrm{I}^{-1}$ while keeping the concentration of $\mathrm{Fe}^{+2}$ and COD constant at $7.72 \mathrm{~g} \mathrm{l}^{-1}$ and 21000 $\mathrm{mg} \mathrm{I}^{-1}$. The $\mathrm{Fe}^{+2}$ and $\mathrm{H}_{2} \mathrm{O}_{2}$ concentrations were varied in the mass ratio $\mathrm{H}_{2} \mathrm{O}_{2} / \mathrm{Fe}^{+2}$ from 2.886 to 14.430 (Fig. 2).

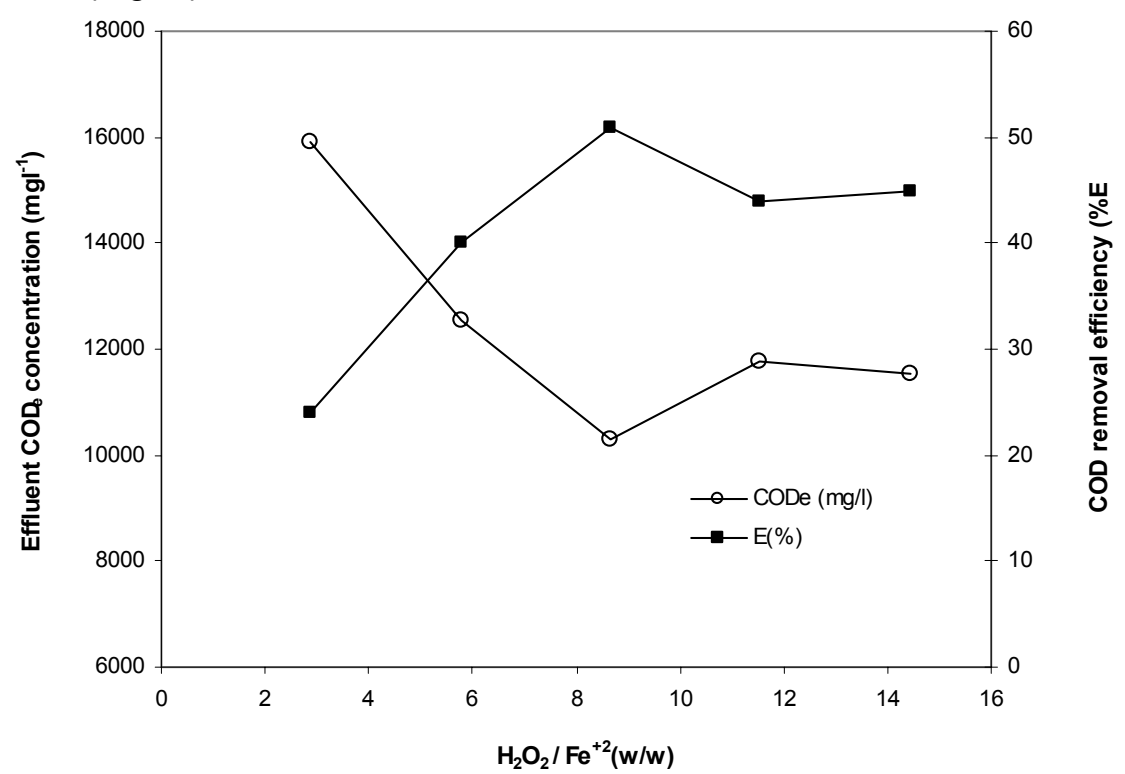

Figure 2. Effect of $\mathrm{H}_{2} \mathrm{O}_{2} / \mathrm{Fe}^{+2}$ ratios on effluent $\mathrm{COD}$ concentration and $\mathrm{COD}$ removal efficiency by Fenton process ( $\mathrm{pH}=3, \mathrm{t}=60 \mathrm{~min}, \mathrm{~T}=39-100^{\circ} \mathrm{C}$ )

The increase on $\mathrm{H}_{2} \mathrm{O}_{2}$ concentration from 22.28 to $66.84 \mathrm{~g} \mathrm{I}^{-1}$ improved the removal of organic matter. However, the extended $\mathrm{H}_{2} \mathrm{O}_{2}$ concentration above $66.84 \mathrm{~g} \mathrm{I}^{-1}$ could not extended COD removal efficiency. The COD degradation decreased from 51 to $45 \%$ as the $\mathrm{H}_{2} \mathrm{O}_{2}$ dose increased from 66.84 to $111.4 \mathrm{~g} \mathrm{I}^{-1}$. This is probably due to both the auto-decomposition of 
$\mathrm{H}_{2} \mathrm{O}_{2}$ into oxygen and water, and the scavenging of hydroxyl radicals by $\mathrm{H}_{2} \mathrm{O}_{2}$ (Rodriguez et al., 2002). The favorable $\mathrm{H}_{2} \mathrm{O}_{2}$ to $\mathrm{Fe}^{+2}$ mass ratio was found to be $8.658(\mathrm{w} / \mathrm{w})$.

The COD removal as a function of the dosage of $\mathrm{Fe}^{+2}$ and $\mathrm{H}_{2} \mathrm{O}_{2}$ were illustrated in Fig. 3 . Different doses of $\mathrm{H}_{2} \mathrm{O}_{2}$ and $\mathrm{Fe}^{+2}$ were selected which yielded the same optimum $\mathrm{H}_{2} \mathrm{O}_{2} / \mathrm{Fe}^{+2}$ mass ratio (8.658). Increasing the $\mathrm{Fe}^{+2}$ concentration to the parallel $\mathrm{H}_{2} \mathrm{O}_{2}$ concentration produces a higher degree of degradation. As could be seen from Figure 3 , the highest COD removal efficiency was achieved after the highest addition of reagents $\left(200.52 \mathrm{~g} \mathrm{l}^{-1} \mathrm{H}_{2} \mathrm{O}_{2}\right.$ and $23.16 \mathrm{~g} \mathrm{I}^{-1} \mathrm{Fe}^{+2}$ ). The COD was decreased to $2980 \mathrm{mg} \mathrm{l}^{-1}$ with $86 \%$ removal at $60 \mathrm{~min}$ reaction time. With $86 \%$ of COD removal, Fenton oxidation has not been found to be satisfactory for oil recovery industry with a high strength of COD. COD discharge limit to receiving waters for oil recovery industry is $250 \mathrm{mg} \mathrm{I}^{-1}$ according to Turkish Water Pollution Control regulation.

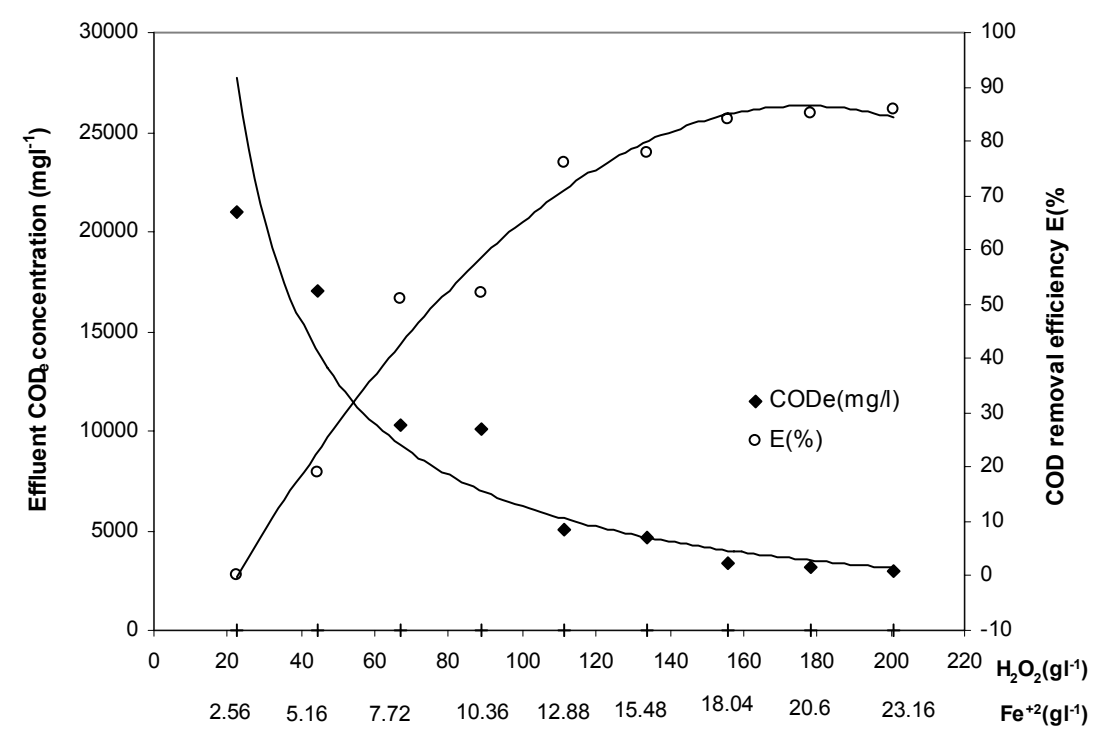

Figure 3. Effect of $\mathrm{H}_{2} \mathrm{O}_{2}\left(\mathrm{~g} \mathrm{l}^{-1}\right)$ and $\mathrm{Fe}^{+2}$ concentration on the effluent $\mathrm{COD}_{\mathrm{e}}$ and $\mathrm{COD}$ removal efficiency $(\%)$ by Fenton process $(\mathrm{pH}=3, \mathrm{~T}=39-100 \circ \mathrm{C}, \mathrm{t}=60 \mathrm{~min}$ )

The experimental results suggest that optimal $\mathrm{H}_{2} \mathrm{O}_{2}$ to $\mathrm{Fe}^{+2}$ ratio has to be maintained to achieve the maximal degradation efficient. Many authors suggested $\mathrm{Fe}^{+2}$ to $\mathrm{H}_{2} \mathrm{O}_{2}$ mass ratio to be optimal at 1 to 10 , but it must be optimised for particular wastewater to minimize scavenging effects (Torrades et al., 2003; San Sebastian et al., 2003).

The reaction is fast and exothermic: temperature measured in our experiments was among $39-100{ }^{\circ} \mathrm{C}$ in the Fenton reactor. Water bath was unable to maintain fixed temperature and the system overheated up to $100^{\circ} \mathrm{C}$. Dutta et al. (2001) stated that there was practically no difference in the rate and extent of degradation of the reaction in the temperature between 40 and $75^{\circ} \mathrm{C}$. Rodriguez et al. (2002) reported that a significant enhancement of DOC reduction efficiency during the photo-Fenton treatment was verified when the temperature was increased from 40 to $60^{\circ} \mathrm{C}$. A plateau is reached above $60^{\circ} \mathrm{C}$.

The recently developed photo Fenton treatment is based on the hydroxyl radical generation by a mixture of $\mathrm{H}_{2} \mathrm{O}_{2}$ to $\mathrm{Fe}^{+2}$ ions.

Fig. 4 shows the COD removal by the photo-Fenton process with a variation of $\mathrm{H}_{2} \mathrm{O}_{2} / \mathrm{Fe}^{+2}$ mass $(\mathrm{w} / \mathrm{w})$ ratios for a reaction time of $30,60,90,120,180$ and 210 min. A turbidity in the solutions during the photo treatment hinders the absorption of the UV light for the photo Fenton process (Rodriguez et al., 2002). Therefore, wastewater was diluted (80\%) and used in photo Fenton and $\mathrm{UV} / \mathrm{H}_{2} \mathrm{O}_{2}$ experiments. The wastewater temperature in the circulation tank varied in the range of $39-43{ }^{\circ} \mathrm{C}$ (photo Fenton and $\mathrm{UV} / \mathrm{H}_{2} \mathrm{O}_{2}$ ).

When $\mathrm{H}_{2} \mathrm{O}_{2}$ dose was fixed at $8.4 \mathrm{~g} \mathrm{I}^{-1}$ and as $\mathrm{Fe}^{+2}$ concentration was increased sequentially from $25,50,100$ and $200 \mathrm{mg} \mathrm{l}^{-1}$, the removal efficiency increased from $75 \%$ to $81 \%$ and then decreased to $71 \%$ and $51 \%$, respectively. This increasing trend is due to that the higher the 
ferrous dosage, the more the $\mathrm{OH}^{*}$ can be formed through reaction, thus leading to a high COD removal. The best COD removal efficiency was obtained with $\mathrm{Fe}^{+2}$ concentration of 50 $\mathrm{mg}^{-1}$. The highest percent COD removal was $81 \%$ after 210 min of oxidation with a $\mathrm{H}_{2} \mathrm{O}_{2}$ l $\mathrm{Fe}^{+2}$ mass ratio of 168 . The dosage of ferrous ions over $50 \mathrm{mg} \mathrm{I}^{-1}$ does not increase the COD removal efficiency. This may be due to the increase of a brown turbidity in the wastewater during the photo-treatment, which hinders the absorption of the UV light required for the photo fenton process and excessive formation of $\mathrm{Fe}^{+2}$, which can compete with the organic carbon for $\mathrm{OH}^{*}$ radical and also fixed $\mathrm{H}_{2} \mathrm{O}_{2}$ concentration can become the limiting factor (Rodriguez et al., 2002).

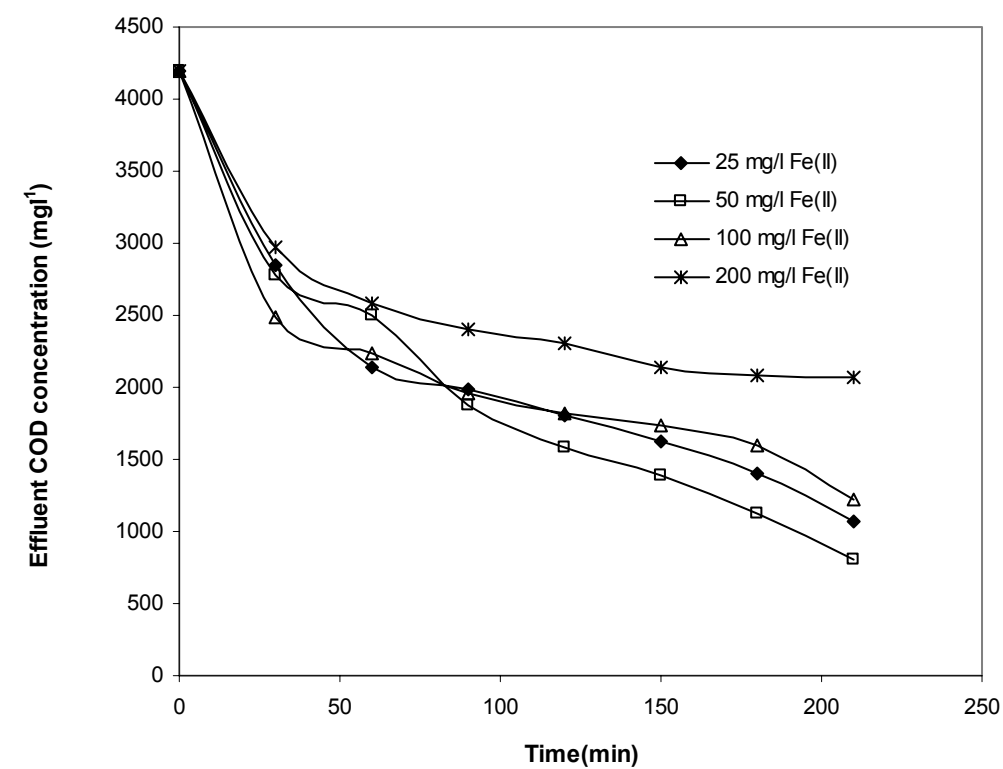

Figure 4. Variation of effluent COD concentration with time different Fe (II) concentration by photo-Fenton process $\left(\mathrm{H}_{2} \mathrm{O}_{2}=8400 \mathrm{mg} \mathrm{l}^{-1}, \mathrm{pH}=3.0, \mathrm{~T}=39-43, \mathrm{COD}_{0}=4200 \mathrm{mg} \mathrm{l}^{-1}\right)$

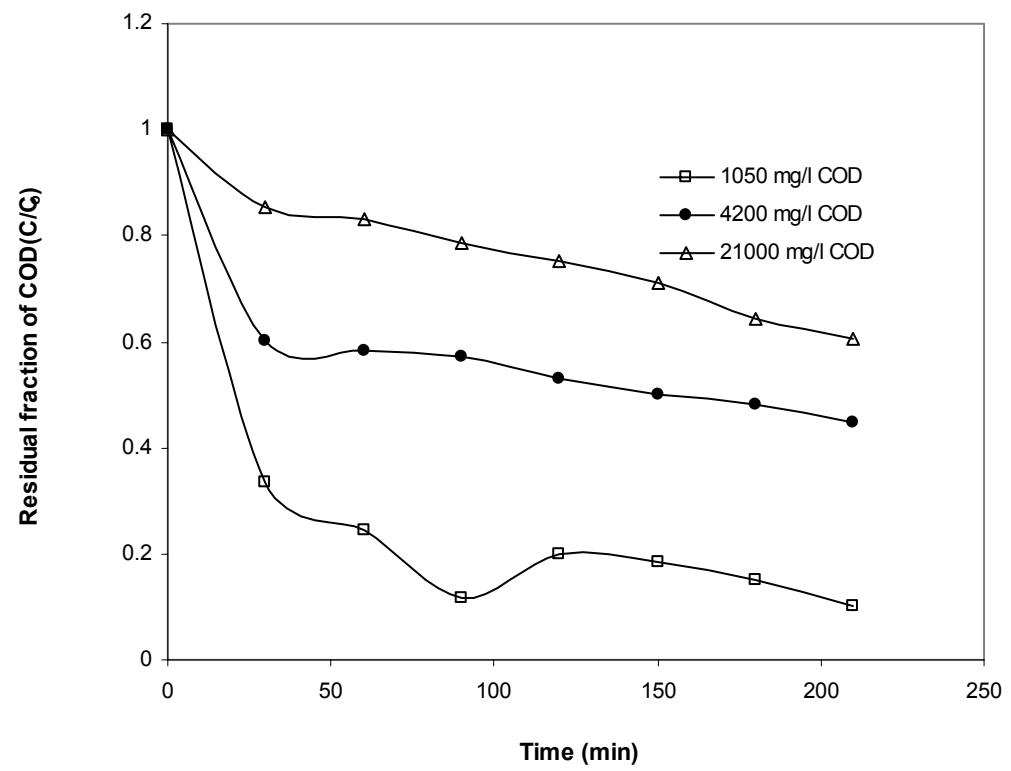

Figure 5. Variation of fraction COD with time different initial COD concentration by $\mathrm{UV} / \mathrm{H}_{2} \mathrm{O}_{2}$ process $\left(\mathrm{COD} / \mathrm{H}_{2} \mathrm{O}_{2}: 1 / 2(\mathrm{w} / \mathrm{w}), \mathrm{T}=39-43^{\circ} \mathrm{C}, \mathrm{pH}=3\right)$

Ultraviolet photolysis combined with hydrogen peroxide was found appropriate oxidation process for treatment of low pollution strength wastewater. The efficiencies of the $U V / \mathrm{H}_{2} \mathrm{O}_{2}$ process in the fix dosage ratios of $\mathrm{COD} / \mathrm{H}_{2} \mathrm{O}_{2}$ are illustrated in Figure 5. The $\mathrm{UV} / \mathrm{H}_{2} \mathrm{O}_{2}$ process 
was able to mineralize $90 \%$ of the initial COD $\left(\operatorname{COD}_{0}: 1050 \mathrm{mg} \mathrm{I}^{-1}\right)$. Lower COD removals were observed when the initial COD concentration exceeded $4200 \mathrm{mg} \mathrm{l}^{-1}$. High initial COD $(\geq 21000$ $\mathrm{mg}^{-1}$ )containing wastewaters did not suffer any appreciable oxidation with the combination of UV radiation and hydrogen peroxide. Reductions of COD can only be as high as $39 \%$ when the initial COD is $21000 \mathrm{mg} \mathrm{l}^{-1}$ and the initial concentration of hydrogen peroxide is $42 \mathrm{~g} \mathrm{I}^{-1}$. High COD wastewaters absorb most of the incident UV radiation, while for lower COD wastewaters hydrogen peroxide is the main absorber (Beltran et al., 1997).

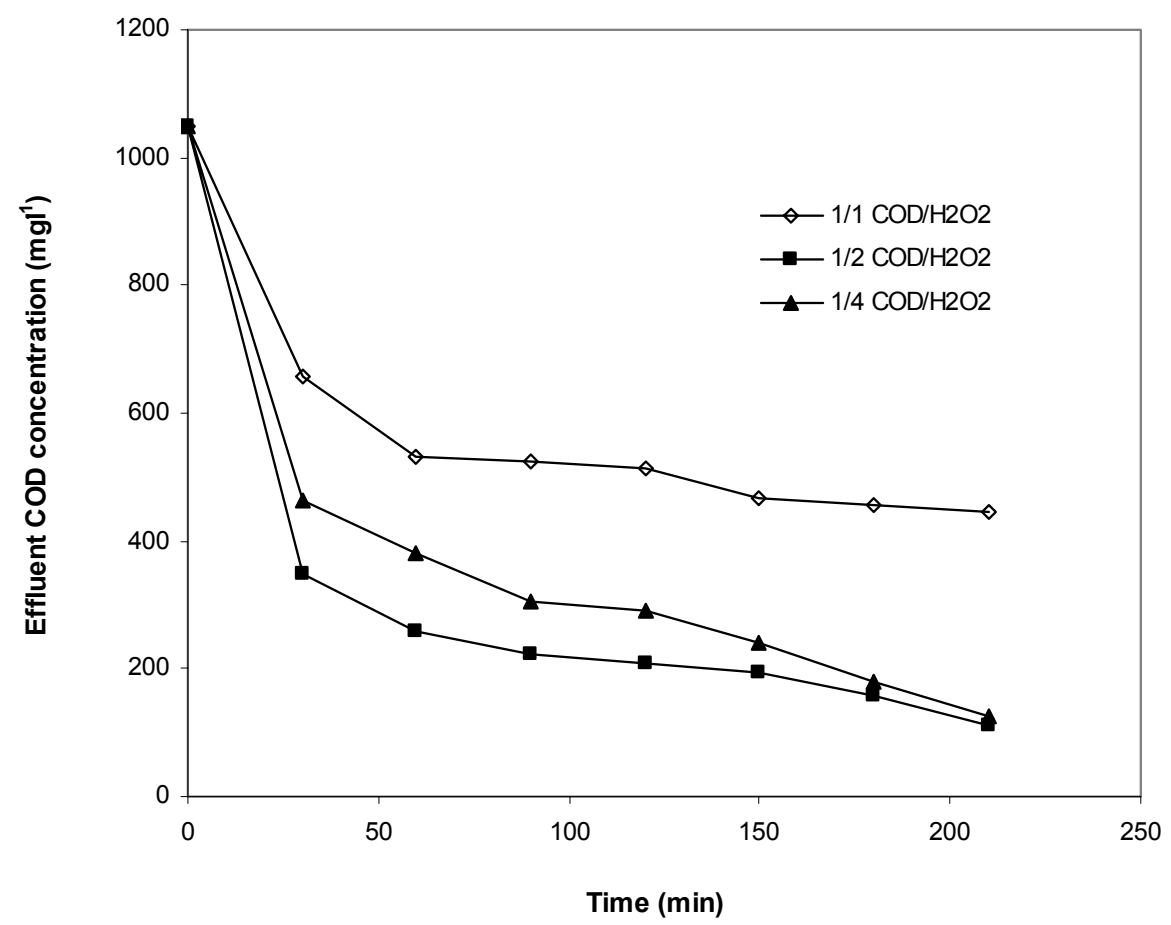

Figure 6. Variation of effluent $\mathrm{COD}$ concentrations with time different $\mathrm{COD} / \mathrm{H}_{2} \mathrm{O}_{2}$ ratios by $\mathrm{UV} / \mathrm{H}_{2} \mathrm{O}_{2}$ process $\left(\mathrm{pH}=3, \mathrm{~T}=39-43^{\circ} \mathrm{C}, \mathrm{COD}=1050 \mathrm{mg} \mathrm{l}^{-1}\right)$

Fig. 6 depicts variations of $\mathrm{COD}$ removal with the different $\mathrm{COD} / \mathrm{H}_{2} \mathrm{O}_{2}$ ratios at a constant initial COD of $1050 \mathrm{mg} \mathrm{l}^{-1}$ for the reaction time of $210 \mathrm{~min}$. The COD/ $\mathrm{H}_{2} \mathrm{O}_{2}$ ratio $(\mathrm{w} / \mathrm{w})$ was found approximately $1 / 2$ for maximum COD removal (initial COD:1050 mg l-1). No improvment on COD removal was obtained when higher $\mathrm{H}_{2} \mathrm{O}_{2}$ concentration was employed, as shown in Fig.6. The contribution of $\mathrm{COD} / \mathrm{H}_{2} \mathrm{O}_{2}$ ratio to $\mathrm{COD}$ removal reached $58 \%, 90 \%$ and $88 \%$ for the dosage ratios of $\mathrm{COD} / \mathrm{H}_{2} \mathrm{O}_{2}$ as $1: 1,1: 2$ and 1:4, respectively. As seen from fig.6, at $1050 \mathrm{mg} \mathrm{I}^{-1} \mathrm{H}_{2} \mathrm{O}_{2}$, COD removal was $58 \%$ and it increased to $90 \%$ when $\mathrm{H}_{2} \mathrm{O}_{2}$ was raised to $2100 \mathrm{mg} \mathrm{I}^{-1}$ due to increase in the formation of $\mathrm{OH}^{*}$. Further increase in $\mathrm{H}_{2} \mathrm{O}_{2}$ dosage $\left(4200 \mathrm{mg} \mathrm{l}^{-1}\right)$ lead to the decrease of COD removal efficiency $(88 \%)$. Excessive amounts of $\mathrm{H}_{2} \mathrm{O}_{2}$ could be attributed to the formation of much less powerful $\mathrm{HO}_{2}$ radicals.

As a result in this study, efficiency of the $\mathrm{UV} / \mathrm{H}_{2} \mathrm{O}_{2}$ process for COD removal is dependent on initial wastewater pollution strength or dilution of wastewater, hydrogen peroxide concentration and reaction time. It was found that the oxidative ability of $\mathrm{UV} / \mathrm{H}_{2} \mathrm{O}_{2}(55 \%)$ is less than that of the $\mathrm{UV} / \mathrm{Fe}^{+2} / \mathrm{H}_{2} \mathrm{O}_{2}(81 \%)$ process alhough both processes destroy $80 \%$ diluted wastewater $\left(\mathrm{COD} / \mathrm{H}_{2} \mathrm{O}_{2}=1 / 2 \mathrm{w} / \mathrm{w}\right)$.

Fenton's reagent commonly requires a relatively short reaction time compared with other AOPs. Thus, Fenton's reagent is frequently used when a high reduction of COD is required (San Sebastian et al., 2003). Bubling was observed in all trials and a rapid boil was observed for tests using higher reagent concentrations. Gas production was more intense when higher reagent concentrations were used.

\section{CONCLUSIONS}

The degradation of wastewater from oil recovery industry was investigated by the Fenton, photo Fenton and $\mathrm{UV} / \mathrm{H}_{2} \mathrm{O}_{2}$ processes. The COD removal efficiency was strongly affected by 
many factors such as the concentration of $\mathrm{H}_{2} \mathrm{O}_{2}, \mathrm{Fe}^{+2}$ and the ratio of organic materials to the Fenton reagents.

The optimum operating conditions of the Fenton oxidation process involve $200.52 \mathrm{mg} \mathrm{I}^{-1}$ $\mathrm{H}_{2} \mathrm{O}_{2}, 23.16 \mathrm{mg} \mathrm{l}^{-1} \mathrm{Fe}^{+2}, 21000 \mathrm{mg} \mathrm{l}^{-1}$ initial COD and $60 \mathrm{~min}$ of treatment time. Under these conditions, the COD removal efficiency was observed to be $86 \%$.

The optimum operating conditions for the photo Fenton oxidation of wastewater was carried out at the given operating conditions $\left(\mathrm{pH} 3 \pm 0.1, \mathrm{Fe}^{+2}: 50 \mathrm{mg} \mathrm{l}^{-1}\right.$ and $\mathrm{H}_{2} \mathrm{O}_{2}: 8400 \mathrm{mg} \mathrm{l}^{-1}, \mathrm{~T}: 39$ $43{ }^{\circ} \mathrm{C}$ ). The optimal ratio $\mathrm{H}_{2} \mathrm{O}_{2} / \mathrm{Fe}^{+2}(\mathrm{w} / \mathrm{w})$ was 168 , which produced a COD removal of $81 \%$ for $80 \%$ diluted wastewater $\left(\mathrm{COD}_{0}: 4200 \mathrm{mg} \mathrm{l}^{-1}\right)$.

As a result of this study, a low COD removal efficiency (39\%) was found for the photo treatment process $\left(\mathrm{UV} / \mathrm{H}_{2} \mathrm{O}_{2}\right)$ without dilution of wastewater. In addition, more $\mathrm{COD}$ was removed at higher COD strengths than lower COD with the same mass ratio $\left(\mathrm{COD} / 2 \mathrm{H}_{2} \mathrm{O}_{2}\right)$ though COD removal efficiency decreased with initial COD.

\section{ACKNOWLEDGEMENTS}

The authors wish to thank the Diktaş Oil Factory for the supporting this study (Çorlu-TekirdağTurkey).

\section{REFERENCES}

Andreozzi R., Caprio V., Insola A., Marotta R. and Sanchırıco R. (2000) Advanced oxidation processes for the treatment of mineral oil contaminated wastewaters, Water Research, 34(2), 620-628.

APHA (1992) Standard Methods for the examination of water and wastewater, 17th ed. Washington DC: American Public Health Association.

Beltran F.J., Gonzalez M., Gonzales JF. (1997) Industrial wastewater advanced oxidation. Part 1. UV radiation in the presence and absence of hydrogen peroxide, Wat. Res., 31(10), 24052414.

Benitez F.J., Acero JL., Gonzalez T., Garcia J. (2001) Organic matter removal from wastewaters of the black olive industry by chemical and biological procedures, Process Biochemistry, $\mathbf{3 7}$, 257-265.

Bolton J.R. (1999) Ultraviolet Applications Handbook, Bolton Photosciences Inc., Ontario.

Chamarro E., Marco A., Esplugas S. (2001) Use of Fenton reagent to improve organic chemical biodegradability, Water Research, 35, 1047-1051.

Dutta K., Mukhopadhyay S., Bhattacharjee., Chaudhuri B. (2001) Chemical oxidation of methylene blue using a Fenton like reaction, J. Hazard. Mater., 84, 57-71.

Fenton H.J.H. (1894) Oxidation of tartaric acid in the presence of iron, Chem. Soc.J., 65,899-910.

Garcia Montano J., Ruiz N., Munoz I., Domenech X., Garcia Hortal J.A., Torrades F., Peral J. (2006) Environmental assessment of different photo-Fenton approaches for commercial reactive dye removal, Journal of Hazardous Materials, 138(2), 218-235.

Huston P.L., Pignatello J.J. (1999) Degradation of selected pesticide active ingredients and commercial formulations in water by the photo-assisted Fenton reaction, Water Research, 33(5), 1238-1246.

Legrini O., Oliveros E., Braun A.M. (1993) Photochemical processes for water treatment, Chem. Rev., 93, 671-698.

McGinnis B.D., Adams V.D., Middlebrooks E.J. (2000) Degradation of Ethylene Glycol in Photo Fenton Systems, Wat. Res., 34(8), 2346-2354.

Rodriguez M., Sarria V., Esplugas S., Pulgarin C. (2002) Photo-Fenton treatment of a biorecalcitrant wastewater generated in textile activities: biodegradability of the phototreated solution, Journal of Photochemistry and Photobiology A: Chemistry, 151, 129-135.

San Sebastian N., Figuls J., Font X., Sanchez A. (2003) Pre-oxidation of an extremely polluted industrial wastewater by the Fenton's reagent, J. Hazard. Mater., 101(3), 315-322.

Tang W.Z., Huang C.P. (1996) Effect of chlorine content of chlorinated phenols on their oxidation kinetics by Fenton's reagent, Chemosphere, 33, 1621-1635.

Torrades F., Perez M., Mansilla H.D., Peral J. (2003) Experimental design of Fenton and photo Fenton reactions for the treatment of cellulose bleaching effluents, Chemosphere, 53(10), 1211-1220. 